\title{
Synthesis of Ribonucleic Acid in Rabbit Blood Cells In Vivo *
}

\author{
Robert H. DeBellis, Norman Gluck, and Paul A. Marks \\ (From the Department of Medicine, College of Physicians \& Surgeons, Columbia University,
} New York, N. Y.)

Erythroid cells constitute a model particularly suitable for study of the relationship between cell maturation and nucleic acid and protein synthesis. Circulating reticulocytes, nonnucleated cells capable of prolonged protein synthesis, are derived from cells in the bone marrow that proceed from an apparently multipotential nucleated stem cell through various stages of increasingly mature or differentiated cell types (2-5). Protein synthesis in reticulocytes proceeds on ribosomes $(6,7)$, in particular those ribosomes characterized by sedimentation coefficients in excess of 110 $\mathrm{S}$, referred to as polyribosomes (8-10). In addition to ribosomal RNA, transfer RNA and, presumably, "messenger" RNA are required for protein synthesis in reticulocytes. In vitro studies have shown that reticulocytes cannot synthesize RNA (8). The present investigations were designed to determine when, in the course of in vivo maturation of erythroid cells, the RNA of reticulocytes is synthesized.

In these experiments, the synthesis of RNA in rabbit erythroid cells in vivo was evaluated by following the time course of incorporation of administered $\mathrm{P}^{32}$ into cellular RNA. The findings indicate that RNA of reticulocytes is synthesized in a relatively early precursor cell stage of erythroid cell maturation. RNA, once synthesized, can remain functional through the reticulocyte stage. Our study also provides evidence that nucleated leukocytes, in contrast to reticulocytes, can synthesize RNA.

\footnotetext{
* Submitted for publication January 3, 1964 ; accepted February 17, 1964.

This work was supported in part by grants CY 2332 and GM 07368 from the U. S. Public Health Service and by grant NSF GB 310 from the National Science Foundation.

A portion of these data was presented at the Annual Meeting of the American Federation for Clinical Investigation, Atlantic City, N. J., May 1963, and appeared in abstract form (1).
}

\section{Methods}

Induction of reticulocytosis in rabbits. Two- to $3-\mathrm{kg}$ rabbits were made anemic by subcutaneous injection of $25 \mathrm{mg}$ phenylhydrazine per day for 4 days (11). This regularly resulted in a reticulocytosis of 60 to $90 \%$.

In vivo labeling of $R N A$ with $P^{s s}$. Twenty-four hours after the last injection of phenylhydrazine, $3 \mathrm{mc}$ of carrier-free $\mathrm{P}^{22}$ (approximately $3 \mathrm{mc}$ per $\mathrm{ml}$ ) was injected intravenously. Samples of blood were then obtained at intervals of from 30 minutes to 17 days. A total of 14 rabbits was studied. In 10 animals, a single sample of blood was obtained at the times indicated below. In 3 experiments, blood was obtained from the same animal at two different time intervals, and in 1 experiment, at three different time intervals. Reticulocyte ribosomal RNA was purified and analyzed for each of these blood samples. The RNA of cells remaining unlysed after "shock" lysis was analyzed for 7 of the blood samples. These samples were drawn at $30 \mathrm{~min}-$ utes and 1 (twice), 3, 20, 22, and 42 hours.

Preparation of blood samples. Blood was obtained by cardiac puncture and collected into heparinized syringes.

A sample was removed for enumeration of the erythrocytes, leukocytes, reticulocytes, and nucleated red blood cells (12). The cells were recovered from the blood by centrifugation at $2,000 \mathrm{rpm}$ for 15 minutes. This and all subsequent procedures were performed at $0^{\circ} \mathrm{C}$. The plasma was removed and discarded, and the cells were washed once with $0.15 \mathrm{M} \mathrm{NaCl}$. The cells were lysed by a short exposure to a hypotonic solution ("shock" lysis) (8). In this procedure, 4 volumes of $\mathrm{MgSO}_{4}, 1.5 \times 10^{-3} \mathrm{M}$, and Tris, $10^{-8} \mathrm{M}, \mathrm{pH} 7.5$ (Solution 1), was added to the washed cells. After 1 minute the solution was restored to isotonicity by addition of an appropriate amount of $1 \mathrm{~N} \mathrm{NaCl}$. This technique preserves leukocytes and tends to disrupt only the red cells (13). To evaluate the contamination of shock lysates by leukocyte RNA, the following experiment was performed. A normal rabbit with $3 \%$ reticulocytosis was given $3 \mathrm{mc}$ of carrier-free $\mathrm{P}^{\mathrm{a}}$ intravenously and exsanguinated 1 hour later. The buffy coat containing leukocytes with $\mathrm{P}^{32}$-labeled RNA was mixed with unlabeled cells prepared from a phenylhydrazine-treated rabbit with $80 \%$ reticulocytosis. This cell mixture was then subjected to shock lysis as described above. The RNA was isolated 1) from the shock lysate and 2) from the sedimented cells and cell debris remaining after shock lysis. Analysis of these RNA preparations by the technique of sucrose gradient centrifugation revealed that 
the RNA of shock lysates had detectable $\mathrm{P}^{32}$ associated only with $4 \mathrm{~S}$ RNA, whereas the RNA of the sediment of the shock lysate had a heterogeneous pattern of $\mathrm{P}^{32}$ similar to that illustrated in Figure 6 . These data indicate that shock lysates represent primarily reticulocytes. The sedimented cells include leukocytes and reticulocyte
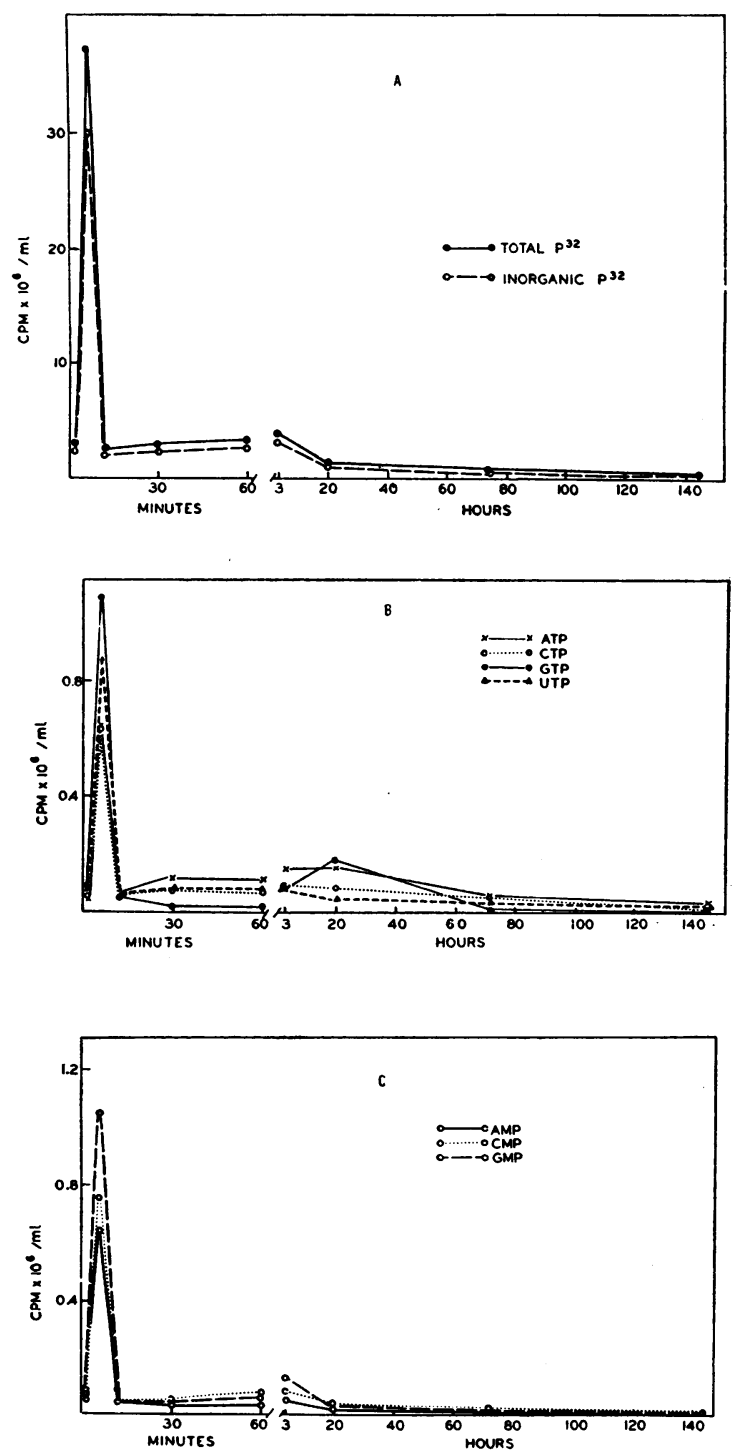

Fig. 1. Time course of disappearance of $P^{32}$-LABELED ACID-SOLUble SUBSTANCE From BLOOD CELLS. A. Total acid-soluble $\mathrm{P}^{32}$ and inorganic $\mathrm{P}^{32} ; \mathrm{B}$. nucleotide triphosphates: $\mathrm{A}=$ adenosine, $\mathrm{C}=$ cytosine, $\mathrm{G}=$ guanosine, and $U=$ uridine; $C$. nucleotide monophosphates. Radioactivity is expressed as counts per minute per milliliter of cell lysate. Uridine monophosphate (UMP) is not illustrated because the values for this nucleotide were falsely high due to contamination by inorganic phosphorus $\left(\mathrm{P}_{1}\right) ; \mathrm{R}_{\mathrm{f}} \mathrm{UMP}=78.2 ; \mathrm{R}_{\mathfrak{f}} \mathrm{P}_{1}=82.5$. stroma and unlysed reticulocytes; this was indicated by direct morphological examination of smears of the sediment.

Isolation and characterization of RNA. RNA was isolated from 1) the total population of washed cells, which includes reticulocytes and leukocytes; 2) shock lysates, which represent primarily reticulocyte lysate; and 3 ) the sedimented cells and cell debris remaining after shock lysis, which include nucleated cells, reticulocyte stroma, and unlysed reticulocytes. The RNA was isolated by a modification of Kirby's procedure (14); all steps were performed at $4^{\circ} \mathrm{C}$. To shock lysates, 0.2 vol of $20 \%$ sodium dodecyl sulphate and 1.2 vol of watersaturated phenol containing $0.1 \%$ 8-hydroxyquinoline were added. The mixture was shaken for 30 minutes. The aqueous and phenol phases were separated by centrifugation at $12,000 \times g$ for 15 minutes, and the phenol phase was re-extracted with 0.5 vol of Solution 1 . The aqueous phase from this extraction was recovered and pooled with the initial aqueous phase. The pooled aqueous phases were re-extracted with 1 vol of water-saturated phenol containing $0.1 \%$ 8-hydroxyquinoline and the phases again separated by centrifugation. Bentonite (15) was added to the aqueous phase to a final concentration of $0.05 \%$ and the mixture centrifuged at $25,000 \times g$ for 15 minutes. The supernatant fluid was recovered, and $\mathrm{NaCl}$ was added to a final concentration of $0.1 \mathrm{~N}$. The RNA was precipitated by the addition of 2 vol of $95 \%$ ethanol. The mixture was then kept at $-20^{\circ} \mathrm{C}$ for a minimum of 8 hours. The precipitated RNA was recovered by centrifugation and redissolved in a minimal volume of 0.1 $\mathrm{N} \mathrm{Na}$ acetate buffer, $\mathrm{pH}$ 5.0. Total washed cells and the sediment of the shock lysis were resuspended in 4 vol of Solution 1 and then processed as described for the shock lysates.

RNA was measured by determining the ultraviolet (UV) absorbance at $260 \mathrm{~m} \mu$. The extinction coefficient for RNA was found to be $24.0 \mathrm{OD}$ per $\mathrm{mg}$, a value in agreement with a previously published figure (16).

RNA was characterized by its sedimentation properties in sucrose gradients $(8,17)$. The conditions of centrifugation are indicated in the legends for the appropriate figures.

Radioactive phosphorus incorporation into purified RNA was determined on fractions of the samples to which $100 \mu \mathrm{g}$ of albumin was added; the mixture was then precipitated in $5 \%$ trichloroacetic acid (TCA) at $0^{\circ} \mathrm{C}$. The precipitates were collected by filtration on Millipore filters, ${ }^{1}$ washed thoroughly with $5 \%$ TCA, dried, and counted in a low-background end window gas-flow counter. All radioactivity measurements were corrected for $\mathrm{P}^{32}$ decay (half-life $=14.3$ days).

Determination of acid-soluble, $P^{s 8}$-labeled substances. For determination of acid-soluble $\mathrm{P}^{32}$ in whole blood, a volume of $10 \%$ TCA was added to an equal volume of whole blood. The insoluble material was removed by

\footnotetext{
1 Millipore Filter Corp., Bedford, Mass.
} 
centrifugation and the radioactivity in the supernatant fluid measured. For determination of intracellular acid-soluble $\mathrm{P}^{32}$, the washed cells were lysed with an equal volume of $10 \% \mathrm{TCA}$, the acid-soluble material was recovered, and its content of $\mathrm{P}^{32}$ was determined.

Chromatographic separation of $\mathrm{P}^{32}$-labeled intracellular acid-soluble substances was carried out by the procedure of Smith and Markham (18), utilizing descending chromatography on Whatman 1 paper and in a 1-dimensional tertiary-butanol, $\mathrm{HCl}$ system. Known nucleotide mono- and triphosphates and carrier-free $\mathrm{P}^{32}$ were used as markers. Radioactivity was measured by cutting the chromatograms into 1-inch horizontal and 5 -inch vertical strips. Each rectangle of paper 1 inch $\times \frac{5}{8}$ inch was counted in the gas-flow counter.

Analysis of base composition of $R N A$. Analysis of the distribution of radioactivity in the nucleotides of the purified RNA labeled with $\mathrm{P}^{32}$ was performed according to the method of Davis, Carlucci, and Roubein (19).

\section{Results}

$P^{32}$ clearance from whole blood and reticulocytes. To evaluate the time course of labeling of the RNA of erythroid cells, one must know the rate of clearance from these cells of $\mathrm{P}^{32}$-labeled precursors of RNA. The rate of clearance of $\mathrm{P}^{32}$-labeled inorganic phosphorus and nucleotides from the peripheral blood was observed. After injection of $\mathrm{P}^{32}$, samples of blood were obtained at intervals between 1.5 minutes and 145 hours. The acidsoluble $\mathrm{P}^{32}$ fraction (which includes inorganic phosphorus and nucleotides) in whole blood and in blood cells was measured. In addition, the intracellular acid-soluble $\mathrm{P}^{32}$-labeled substances were partitioned by chromatography (18) so that both inorganic and organic fractions could be measured separately.

By 6 minutes after $\mathrm{P}^{32}$ administration, the maximal level was reached of radioactivity of inorganic phosphate and of the mono- and trinucleotides in the whole blood, and, more significantly, in the intracellular pools. At $12 \mathrm{~min}$ utes after injection of the isotope, the radioactivity in the intracellular acid-soluble components had decreased to $6.6 \%$ or less of the maximal observed values (Figure 1). This indicates that clearance of $\mathrm{P}^{32}$ was rapid, and the label in RNA was probably incorporated predominantly within 30 minutes after isotope administration. Previous in vitro studies with rabbit blood cells demonstrated that in those cells capable of RNA synthesis, i.e., leukocytes, incubation with $\mathrm{P}^{\mathbf{3 2}}$ for 3

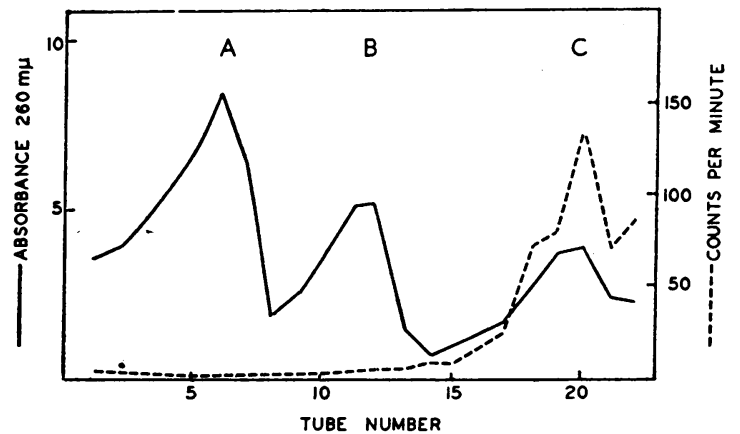

Fig. 2. Sedimentation of PURIfied RNA LABeled in vivo wIrH $\mathrm{P}^{32}$. RNA was isolated from shock lysates of washed blood obtained 30 minutes after the iv administration of $\mathrm{P}^{32}$. Peaks $\mathrm{A}$ and $\mathrm{B}$ correspond to ribosomal RNA with sedimentation coefficients of $28 \mathrm{~S}$ and $18 \mathrm{~S}$ respectively; peak $\mathrm{C}$ corresponds to transfer RNA with a sedimentation coefficient of $4 \mathrm{~S}$. Conditions of centrifugation-linear gradients of 5 to $20 \%$ sucrose in $0.1 \mathrm{~N} \mathrm{Na}$ acetate buffer, $\mathrm{pH} 5.0$ (total volume of $24 \mathrm{ml}$ ), were overlaid with $1 \mathrm{ml}$ of purified RNA in the above buffer and centrifuged in the SW 25.1 rotor for 15 hours at $23,000 \mathrm{rpm}$ with the model L-HV Spinco ultracentrifuge at a starting temperature of $4^{\circ} \mathrm{C}$.

minutes was sufficient to label each of the four nucleotides of RNA (20).

Time course of incorporation of $P^{32}$ into reticulocyte RNA. RNA purified from shock lysates and analyzed on sucrose density gradients separated into three major UV absorbing peaks (Figure 2). Based on studies of mammalian RNA, sedimentation coefficients of $4 \mathrm{~S}, 18 \mathrm{~S}$, and $28 \mathrm{~S}$, respectively, have been assigned to these peaks $(21,22)$. The slowest sedimenting component, corresponding to a sedimentation coefficient of $4 \mathrm{~S}$, presumably represents primarily transfer RNA, and the remaining two peaks correspond to ribosomal RNA (23).

Radioactivity was associated with the $4 \mathrm{~S}$ component in as short a time as 30 minutes after $\mathrm{P}^{\mathbf{3 2}}$ administration. At this time no detectable label was associated with ribosomal RNA corresponding to $18 \mathrm{~S}$ and $28 \mathrm{~S}$ RNA (Figure 2). The low level of $\mathrm{P}^{32}$ associated with the $4 \mathrm{~S}$ component at 30 minutes need not reflect synthesis of this RNA. Radioactivity in the $4 \mathrm{~S}$ component could be the result of incorporation of the $\mathrm{P}^{32}$ into the terminal adenosine monophosphate of transfer RNA. Holt, Herbert, and Joel (24) have shown that more than $95 \%$ of the $\mathrm{P}^{32}$ in- 


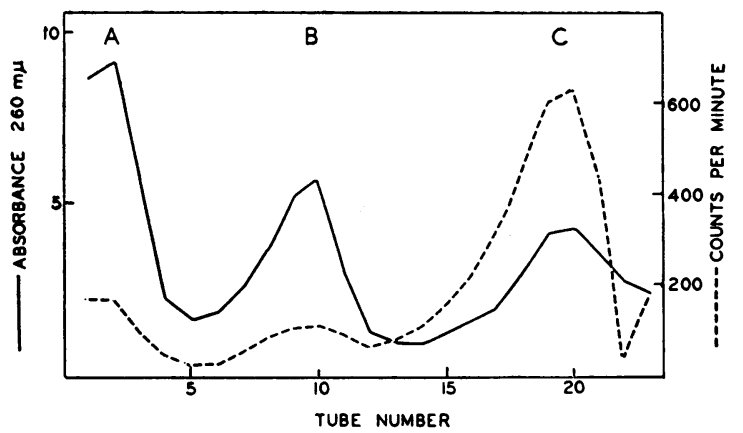

Fig. 3. Sedimentation of PURified RNA LABEled in vivo WITH $\mathrm{P}^{32}$. RNA was isolated from shock lysates of washed cells obtained 3 hours after the iv administration of $\mathrm{P}^{32}$. Components $\mathrm{A}, \mathrm{B}$, and $\mathrm{C}$ and conditions of centrifugation are described in the legend for Figure 2, except that centrifugation was performed for $15 \frac{1}{2}$ hours in the model $\mathrm{L}$ ultracentrifuge.

corporated into the $4 \mathrm{~S}$ RNA by rabbit reticulocytes in vitro is located in the phosphorus of the terminal nucleotides.

Reticulocyte ribosomal RNA, as represented by " 18 S" and " 28 S" RNA, remained virtually unlabeled for the first 2 hours after $\mathrm{P}^{32}$ administration. By 3 to 5 hours, $\mathrm{P}^{32}$ associated with ribosomal RNA was detected. The specific radioactivities of $18 \mathrm{~S}$ and $28 \mathrm{~S}$ RNA were approximately equal (Figure 3 ). With longer periods of in vivo labeling there was a progressive rise in the specific activity of the $18 \mathrm{~S}$ and $28 \mathrm{~S}$, as well as of the $4 \mathrm{~S}$, components with a maximal value being reached at 40 to 42 hours

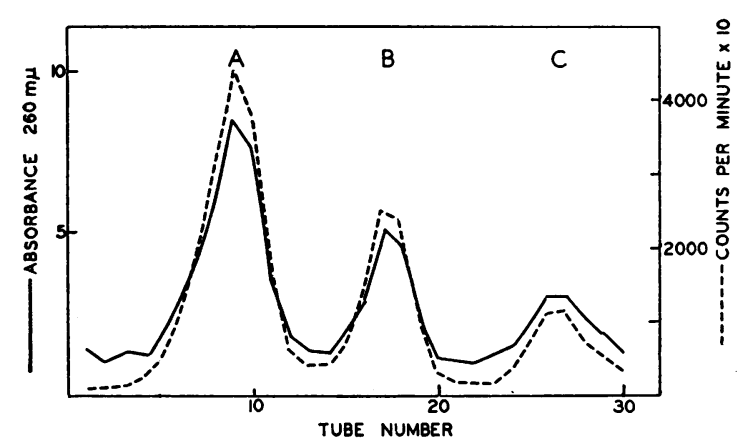

Fig. 4. Sedimentation of purified RNA Labeled in vivo WITH $\mathrm{P}^{32}$. RNA was isolated from shock lysates of washed cells obtained 42 hours after the iv administration of $\mathrm{P}^{32}$. Components $\mathrm{A}, \mathrm{B}$, and $\mathrm{C}$ and conditions of centrifugation are described in the legend for Figure 2, except that centrifugation was performed for $14 \frac{1}{2}$ hours in the model L Spinco ultracentrifuge.
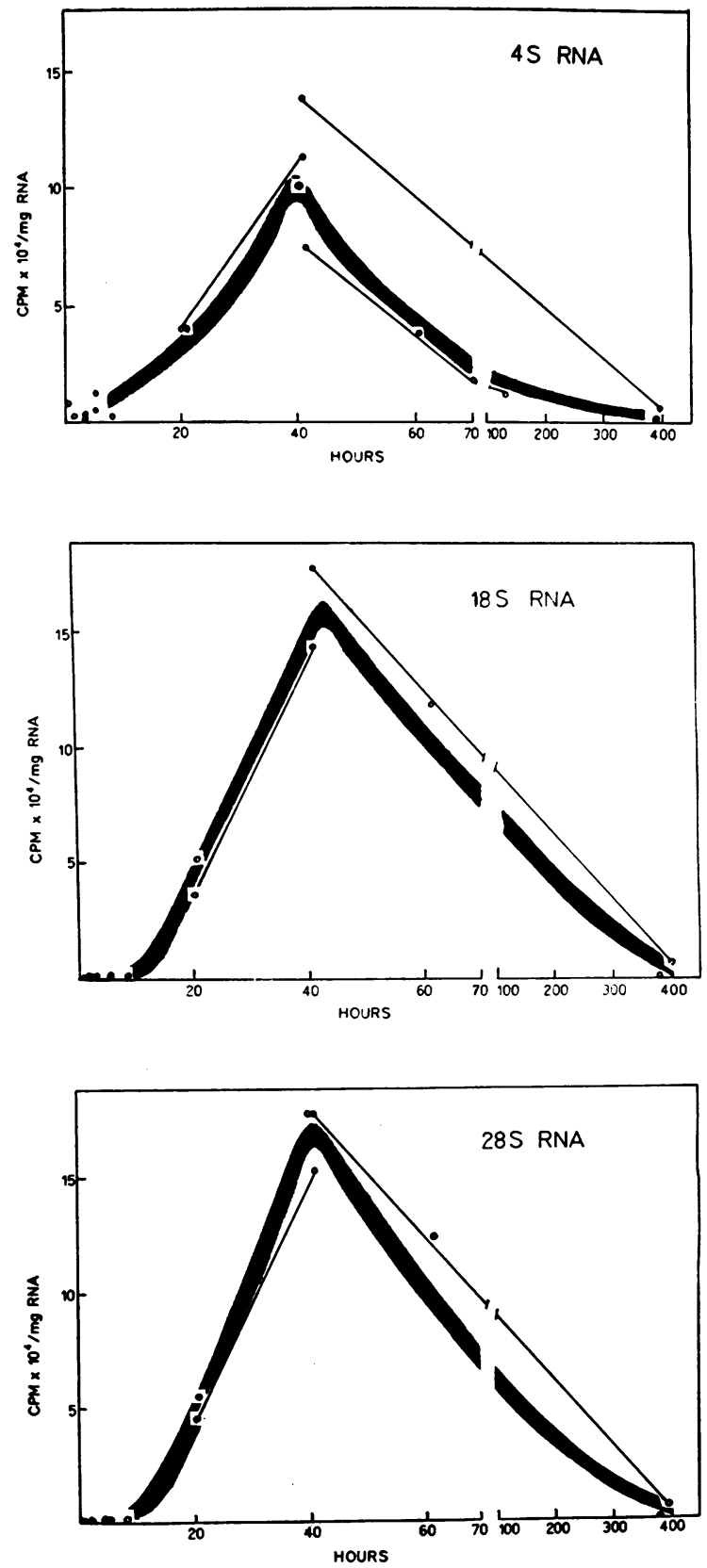

Fig. 5. Time course of APPEARANCE OF LABEled RNA In CirCUlating Reticulocytes. The specific radioactivity of the $28 \mathrm{~S}, 18 \mathrm{~S}$, and $4 \mathrm{~S}$ RNA purified from shock lysates of blood obtained at the times indicated after $\mathrm{P}^{22}$ was administered. Each point represents one determination on a given animal. Multiple samples from the same animal are shown as connected points. Specific radioactivity of the RNA was determined for the peak tube for each of the components separated by sedimentation in sucrose density gradients. Shaded line was drawn by eye to fit all the points. 
TABLE I

Base analysis of alkaline hydrolysates of ribosomal $R N A$ purified from reticulocytes*

\begin{tabular}{|c|c|c|c|c|c|}
\hline $\begin{array}{l}\text { Ribosomal } \\
\text { RNA } \\
\text { fraction }\end{array}$ & Analysis & AMP & GMP & CMP & UMP \\
\hline $28 \mathrm{~S}$ & $\begin{array}{l}\text { Ultraviolet } \dagger \\
\text { Radioactive }\end{array}$ & $\begin{array}{c}\% \\
16.0 \\
16.9\end{array}$ & $\begin{array}{c}\% \\
35.9 \\
34.8\end{array}$ & $\begin{array}{c}\% \\
32.5 \\
30.9\end{array}$ & $\begin{array}{c}\% \\
15.8 \\
17.4\end{array}$ \\
\hline $18 \mathrm{~S}$ & $\begin{array}{l}\text { Ultraviolet } \\
\text { Radioactive }\end{array}$ & $\begin{array}{l}20.2 \\
20.8\end{array}$ & $\begin{array}{l}30.3 \\
31.2\end{array}$ & $\begin{array}{l}29.8 \\
27.8\end{array}$ & $\begin{array}{l}19.7 \\
20.1\end{array}$ \\
\hline
\end{tabular}

* RNA was purified from shock lysates of washed cells obtained 42 hours after P32 administration. The purified RNA was fractionated into $18 \mathrm{~S}$ and $28 \mathrm{~S}$ components by sedimentation in sucrose density gradients. Analysis of RNA isolated from reticulocytes harvested 8 hours after $P^{32}$ administration yielded results similar to those presented above.

Abbreviations: AMP $=2^{\prime}, 3^{\prime}$-adenosine monophosphate; GMP = 2', 3'-guanosine monophosphate; CMP = 2', 3'cytosine monophosphate; UMP $=2^{\prime}, 3^{\prime}$-uridine monophosphate.

+ Ultraviolet analysis was performed by eluting each nucleotide monophosphate with 3 to $4 \mathrm{ml}$ of $0.1 \mathrm{~N} \mathrm{HCl}$. The ultraviolet absorption of each nucleotide was measured at its absorption maximum, $\mathrm{Am}\left(\mathrm{Am}_{\mathrm{AMP}}=257 \mu \mathrm{l} ; \mathrm{Am} \mathrm{GMP}_{\mathrm{MP}}=256 \mu \mathrm{l} ;\right.$ $\left.A_{\text {СMP }}=280 \mu \mathrm{l} ; \mathrm{Am}_{\mathrm{UMP}}=262 \mu \mathrm{l}\right)$, and converted to millimicromoles of nucleotide using known extinction coefficients for the above absorption maxima at $\mathrm{pH}_{2}, \mathrm{Em}\left(\mathrm{Em}_{\mathrm{AMP}}=0.0151\right.$ per m $\mu$ mole AMP; Em $\mathrm{AMP}=0.0122$ per m $\mu \mathrm{mole} \mathrm{GMP}$; $\mathrm{Em}_{\mathrm{CMP}}=0.0130$ per $\mathrm{m} \mu$ mole CMP; Em $\mathrm{m}_{\mathrm{UP}}=0.0100$ per m $\mu$ mole UMP) (41). Each mononucleotide is expressed as per cent of total millimicromoles of nucleotide.

(Figures 4 and 5 ). The peak specific activity of ribosomal RNA at 40 to 42 hours is approximately 200 -fold that at 3 hours. Low levels of radioactivity associated with all RNA components were still detectable after periods of 17 days (Figure 5). In part, this may represent a reutilization of mononucleotides and other $\mathrm{P}^{32}$-labeled RNA precursors during the breakdown of RNA.

Firm evidence that the $\mathrm{P}^{32}$ associated with reticulocyte RNA at $\mathbf{4 2}$ hours represented newly synthesized nucleic acid and not merely terminal nucleotide exchange was provided by determining the distribution of radioactivity in the nucleotides of the various RNA components. An excellent correspondence was found between the nucleotide composition based on absorbancy measurements and $\mathrm{P}^{32}$ radioactivity assays of the RNA ( $\mathrm{Ta}$ ble I). A distinct difference between the base composition of $28 \mathrm{~S}$ and $18 \mathrm{~S}$ RNA was observed. This agrees with recent findings that the two ribosomal RNA molecules in the developing chick embryo differ in their base composition (25). These observations are consistent with the demonstration that in Escherichia coli the two components of ribosomal RNA are derived from different loci on the DNA (26).

At no time did the analysis of the total RNA of reticulocytes reveal a labeled component present in trace amounts, i.e., a component not corresponding to one of the major peaks of RNA.

Time course of incorporation of $P^{32}$ into $R N A$ of sediment of shock lysis. RNA was purified from the sediment of the shock lysis, which includes leukocyte and reticulocyte RNA. This RNA, analyzed on sucrose density gradients, separated into three major UV absorbing components that were similar to those observed with reticulocyte RNA. However, this RNA isolated between $\frac{1}{2}$ hour and 2 hours after $\mathrm{P}^{32}$ administration showed a labeled component that sedimented diffusely through the gradient and had no apparent association with any of the three major RNA components (Figure 6). This heterogeneous RNA component was still present at 5 hours

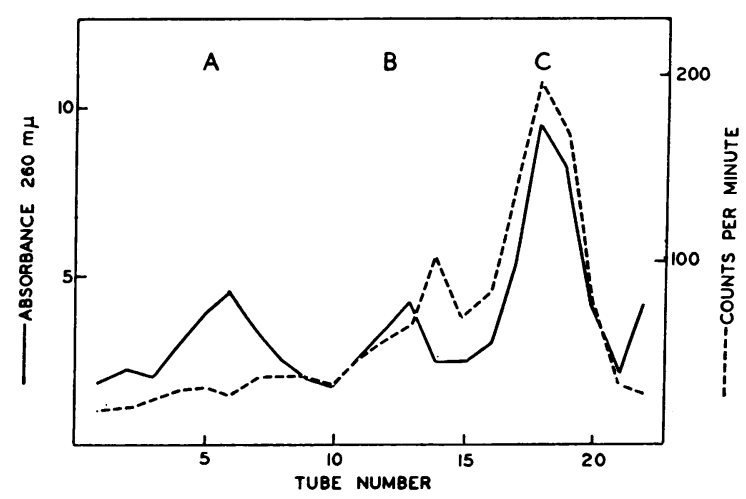

Fig. 6. Sedimentation of PURIFied RNA LAbeled in vivo WITH $\mathrm{P}^{32}$. RNA was isolated from the sedimented cells and cell debris remaining after shock lysis of washed blood obtained $\frac{1}{2}$ hour after the iv administration of $\mathrm{P}^{32}$. Components $\mathrm{A}, \mathrm{B}$, and $\mathrm{C}$ and conditions of centrifugation are described in Figure 2. 


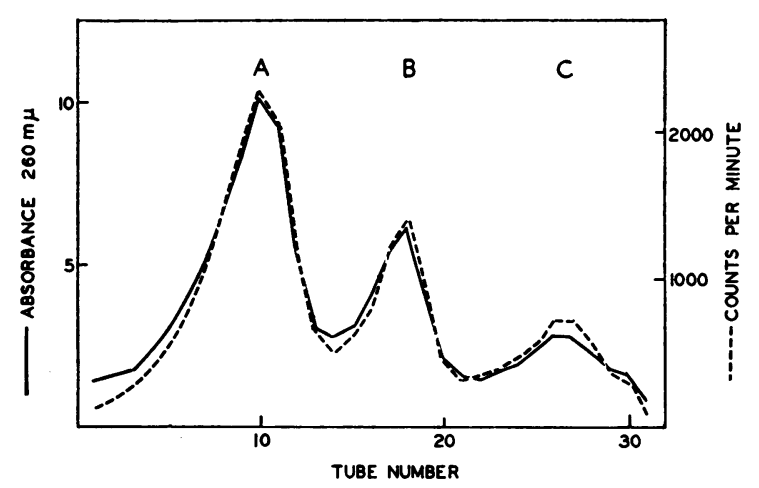

Fig. 7. Sedimentation of PURIfied RNA Labeled in vivo WITH $\mathrm{P}^{32}$. RNA was isolated from the sedimented cells and cell debris remaining after shock lysis of washed blood cells obtained 20 hours after the iv administration of $\mathrm{P}^{32}$. Components $\mathrm{A}, \mathrm{B}$, and $\mathrm{C}$ and conditions of centrifugation are described in Figure 2, except that centrifugation was carried out for $15 \frac{1}{2}$ hours.

after $\mathrm{P}^{32}$ administration. In RNA prepared from the sediment of the shock lysis 20 hours after $\mathrm{P}^{32}$ administration, this diffusely sedimenting labeled component was no longer detectable (Figure 7 ), and the pattern of distribution of the $\mathrm{P}^{32}$ followed closely the distribution of UV absorbing material. $\mathrm{P}^{32}$-labeled ribosomal RNA could first be detected in RNA purified from the sediment of the shock lysis recovered 3 hours after injection of $\mathrm{P}^{32}$. Although ribosomal RNA may be labeled at earlier times, the presence of a $\mathrm{P}^{32}$ labeled heterogeneous component could interfere with its identification.

The pattern of $\mathrm{P}^{32}$ incorporation into RNA of the sediment of the shock lysis, purified at $\frac{1}{2}$ to 2 hours after isotope administration, most likely reflects leukocyte RNA. No $\mathrm{P}^{32}$-labeled RNA, other than that associated with $4 \mathrm{~S}$ material, is detectable in shock lysates that contain reticulocyte RNA but essentially no leukocyte RNA. Further, in vitro studies demonstrate that circulating leukocytes are capable of relatively rapid synthesis of ribosomal RNA (20). At 20 hours, the pattern of $\mathrm{P}^{32}$ incorporation into RNA purified from the sediment of the shock lysis reflects leukocyte and reticulocyte $\mathrm{P}^{32}$-labeled RNA and cannot be interpreted in terms of the pattern of synthesis of one or the other type of cell, since the relative amounts of leukocytes and reticulocytes in the sediment are not known.

\section{Discussion}

Reticulocytes cannot synthesize RNA in vitro (8). In this study, we found that, after $\mathrm{P}^{32}$ administration to anemic rabbits, the maximal level of radioactivity in RNA of circulating reticulocytes is not achieved for 40 to 42 hours, and no labeled reticulocyte ribosomal RNA is detectable for at least 2 to 3 hours. Taken together, these observations indicate that the RNA in circulating reticulocytes must be synthesized at an earlier stage in erythroid cell maturation.

Based on the work of several previous investigators (e.g., 2-5, 27), an approximate time sequence of erythroid cell maturation can be constructed. The earliest identifiable cell in the erythroid series is the proerythroblast. In animals without anemia, it is estimated that four divisions ensue from the early erythroblast through the basophilic normoblast and polychromatophilic normoblast stages to the orthochromic normoblast stage. At this stage in maturation, no further cell division occurs, and the reticulocytes are formed presumably by extrusion of the nucleus (28). Estimates have been made $(2-5,27,29)$ that the generation time of the various stages of erythroid maturation is approximately 15 to 24 hours. In animals made anemic by blood loss or phenylhydrazine, evidence indicates that erythropoietic stimulation involves fewer divisions rather than an alteration in generation time $(2,27,30)$. Thus, these authors suggested that a polychromatophilic normoblast or a basophilic normoblast may mature directly to a reticulocyte which is released into the circulation. Our finding that maximally labeled RNA in circulating reticulocytes of anemic rabbits appears approximately 40 to 42 hours after administration of $\mathrm{P}^{32}$ (Figure 5) suggests that maximal RNA synthesis occurs at a relatively early precursor erythroid stage, probably before the orthochromic normoblast. The presence of labeled ribosomal RNA in circulating reticulocytes as early as $\mathbf{3}$ to $\mathbf{5}$ hours after $\mathrm{P}^{32}$ administration could represent synthesis in a late basophilic or polychromatophilic normoblast just before its maturation to a reticulocyte and release into the circulation. These interpretations agree with the findings and conclusions of Borsook, Lingrel, Scaro, and Millette (2) 
based on radioautographic observations on the time course of incorporation of tritiated uridine into bone marrow cells of rabbits with an anemia comparable to that of the animals used in this study. Grasso, Swift, and Ackerman (31) have suggested that RNA synthesis by erythroid cells ceases at a stage before the basophilic normoblast when the nucleolus is lost. The available data permit no definitive conclusion; however, the present findings are more consistent with the interpretation that the synthesis of RNA continues beyond the basophilic normoblast. Although there is considerable evidence that the nucleolus is an active site of RNA synthesis (32), its presence is not required for the formation of RNA in nuclei (33).

A rapidly labeled RNA, heterogeneous in its sedimentation characteristics and not corresponding to the major components of RNA, was found in leukocytes. Similar findings have been reported for several other mammalian cells, including human amniotic cells (34) and Hela cells in tissue culture (35) and also chick embryo (25), liver (36), and leukocytes of rats, normal humans, and patients with chronic lymphatic leukemia (37). This relatively rapidly synthesized RNA fraction, present in trace amounts in these cells, may include messenger RNA, i.e., that RNA which transfers information from DNA and becomes attached to ribosomes $(20,25,35-37)$ and possibly to ribosomal precursor RNA.

No rapidly synthesized heterogeneous RNA was demonstrable in reticulocytes, further indicating that these cells do not make messenger RNA. It is likely that the informational RNA in reticulocytes exists in a complex with ribosomes forming the polyribosomes that are established as the site of protein synthesis in these cells (8-10). These observations support the concept that the ribosome complex associated with the information directing protein synthesis in reticulocytes is relatively stable, being synthesized at an earlier precursor cell stage of maturation. As previously suggested (8), the hypothesis that a relatively stable form of RNA contains the information for protein synthesis probably need not be restricted to erythroid cells that mature to a nonnucleated form. Evidence (35-40) has accumulated to suggest that this concept may have broader applicability, particularly to mammalian cells that achieve a fixed stage of differentiation.

\section{Summary}

Rabbits with a phenylhydrazine-induced reticulocytosis were given $\mathrm{P}^{32}$, and a study was made of the time course of incorporation of this precursor into various components of the RNA isolated from circulating blood cells.

No radioactivity was associated with reticulocyte ribosomal RNA before 2 to 3 hours after injection of the isotope. The maximal level of specific activity of reticulocyte RNA was achieved at 40 to 42 hours after $\mathrm{P}^{32}$ administration. In contrast to reticulocytes, nucleated leukocytes contained a heterogeneously sedimenting labeled RNA component within 30 minutes after being introduced to the isotope. These data suggest that reticulocyte RNA is synthesized predominantly before the orthochromic normoblast stage of erythroid cell maturation. The RNA in reticulocytes that directs protein synthesis is probably associated in a relatively stable form with the polyribosomes.

\section{Acknowledgment}

The authors express their thanks to Dr. Rifka Rudner for advice concerning methods for performing base analyses.

\section{References}

1. DeBellis, R. H., N. Gluck, and P. A. Marks. Ribonucleic acid (RNA) synthesis in rabbit blood cells in vivo. Clin. Res. 1963, 11, 192.

2. Borsook, H., J. B. Lingrel, J. L. Scaro, and R. L. Millette. Synthesis of hæmoglobin in relation to the maturation of erythroid cells. Nature (Lond.) 1962, 196, 347.

3. Lajtha, L. G. On DNA labeling in the study of the dynamics of bone marrow cell populations in The Kinetics of Cellular Proliferation, F. Stohlman, Jr., Ed. New York, Grune \& Stratton, 1959, p. 173.

4. Bond, V. P., T. M. Fliedner, E. P. Cronkite, J. R. Rubini, and J. S. Robertson. Cell turnover in blood and blood forming tissues studied with tritiated thymidine in The Kinetics of Cellular Proliferation, F. Stohlman, Jr., Ed. New York, Grune \& Stratton, 1959, p. 188. 
5. Alpen, E. L., and D. Cranmore. Observations on the regulation of erythropoiesis and on cellular dynamics by $\mathrm{Fe}^{50}$ autoradiography in The Kinetics of Cellular Proliferation, F. Stohlman, Jr., Ed. New York, Grune \& Stratton, 1959, p. 290.

6. Schweet, R., H. Lamfrom, and E. Allen. The synthesis of hemoglobin in a cell-free system. Proc. nat. Acad. Sci. (Wash.) 1958, 44, 1029.

7. Dintzis, H. M., H. Borsook, and J. Vinograd. Microsomal structure and hemoglobin synthesis in the rabbit reticulocyte in Microsomal Particles and Protein Synthesis, R. B. Rogers, Ed. New York, Pergamon Press, 1958, p. 95.

8. Marks, P. A., E. R. Burka, and D. Schlessinger. Protein synthesis in erythroid cells. I. Reticulocyte ribosomes active in stimulating amino acid incorporation. Proc. nat. Acad. Sci. (Wash.) 1962, 48, 2163.

9. Warner, J. R., A. Rich, and C. E. Hall. Electron microscope studies of ribosomal clusters synthesizing hemoglobin. Science 1962, 138, 1399.

10. Gierer, A. Function of aggregated reticulocyte ribosomes in protein synthesis. J. molec. Biol. 1963, 6, 148.

11. Borsook, H., E. H. Fisher, and G. Keighley. Factors affecting protein synthesis in vitro in rabbit reticulocytes. J. biol. Chem. 1957, 229, 1059.

12. Jones, A. R., and G. A. Daland in A Syllabus of Laboratory Examinations in Clinical Diagnosis, L. B. Page and P. J. Culver, Eds. Cambridge, Harvard University Press, 1960, pp. 52 and 60.

13. Fallon, H. J., E. Frei III, J. D. Davidson, J. S. Trier, and D. Burk. Leukocyte preparations from human blood: evaluation of their morphologic and metabolic state. J. Lab. clin. Med. 1963, 59, 779.

14. Kirby, K. S. Ribonucleic acids. II. Improved preparation of rat liver ribonucleic acid. Biochim. biophys. Acta (Amst.) 1962, 55, 454.

15. Fraenkel-Conrat, H., B. Singer, and A. Tsugita. Purification of viral RNA by means of bentonite. Virology 1961, 14, 54.

16. Sueoka, N., and T. Yamane. Fractionation of aminoacyl-acceptor RNA on a methylated albumin column. Proc. nat. Acad. Sci. (Wash.) 1962, 48, 1454.

17. Britten, R. J., and R. B. Roberts. High-resolution density gradient sedimentation analysis. Science 1960, 131, 33.

18. Smith, J. D., and R. Markham. Chromatographic studies on nucleic acids. 2. The quantitative analysis of ribonucleic acids. Biochem. J. 1950, 46, 509.

19. Davis, F. F., A. F. Carlucci, and I. F. Roubein. Trace nucleotides in certain ribonucleic acids from yeast. J. biol. Chem. 1959, 234, 1525.

20. Marks, P. A., C. Willson, J. Kruh, and F. Gros. Unstable ribonucleic acid in mammalian blood cells. Biochem. biophys. Res. Commun. 1962, 8, 9.

21. Hall, B. D., and P. Doty. The preparation and physical chemical properties of ribonucleic acid from microsomal particles. J. molec. Biol. 1959, 1, 111.

22. Ts'o, P. O. P., and R. Squires. Quantitative isolation of intact RNA from microsomal particles of pea seedlings and rabbit reticulocytes. Fed. Proc. 1959, 18, 341.

23. Spirin, A. S. Some problems concerning the macromolecular structure of ribonucleic acid in Progress in Nucleic Acid Research, J. N. Davison and W. E. Cohn, Eds. New York, Academic Press, 1963, vol. 1, p. 201.

24. Holt, C. E., E. Herbert, and P. B. Joel. RNA metabolism of intact rabbit reticulocytes. Fed. Proc. 1962, 21, 381.

25. Lerner, A., E. B. Martin, and J. E. Darnell, Jr. Ribosomal RNA in the developing chick embryo. Science 1963, 140, 1187.

26. Yankof sky, S. A., and S. Spiegelman. Distinct cistrons for the two ribosomal RNA components. Proc. nat. Acad. Sci. (Wash.) 1963, 49, 538.

27. Brecher, G., and F. Stohlman, Jr. The macrocytic response to erythropoietin stimulation in Erythropoiesis, L. O. Jacobson and M. Doyle, Eds. New York, Grune \& Stratton, 1962, p. 216.

28. Bessis, M. Cytology of the Blood and Blood Forming Organs. New York, Grune \& Stratton, 1956, p. 232.

29. Bond, V. P., N. Odartchenko, H. Cottier, L. E. Feinendegen, and E. P. Cronkite. The kinetics of the more mature erythrocytic precursors studied with tritiated thymidine in Erythropoiesis, L. O. Jacobson and M. Doyle, Eds. New York, Grune \& Stratton, 1962, p. 173.

30. Stohlman, F., Jr. Regulation of erythropoiesis. Trans. N. Y. Acad. Sci. 1962, 24, 312.

31. Grasso, J. A., H. Swift, and G. A. Ackerman. Observations on the development of erythrocytes in mammalian fetal liver. J. Cell Biol. 1962, 14, 235.

32. Brachet, J. The Biological Role of Ribonucleic Acids. Amsterdam, Elsevier, 1960, p. 102.

33. Busch, H., P. Byvoet, and K. Smetana. The nucleolus of the cancer cell: a review. Cancer Res. 1963, 23, 313.

34. Cheng, P-Y. Size of rapidly labelled ribonucleic acids in human amnion cells. Biochim. biophys. Acta (Amst.) 1961, 53, 235.

35. Penman, S., K. Scherrer, Y. Becker, and J. E. Darnell. Polyribosomes in normal and poliovirusinfected Hela cells and their relationship to messenger-RNA. Proc. nat. Acad. Sci. (Wash.) 1963, 49, 654.

36. Hiatt, H. H. A rapidly labeled RNA in rat liver nuclei. J. molec. Biol. 1962, 5, 217. 
37. DeBellis, R. H., and P. A. Marks. Rapidly synthesized RNA of normal and neoplastic cells. Proc. Amer. Ass. Cancer Res. 1963, 4, 14.

38. Reich, E., R. M. Franklin, A. J. Shatkin, and E. L. Tatum. Action of actinomycin D on animal cells and viruses. Proc. nat. Acad. Sci. (Wash.) 1962, 48, 1238.

39. Tyler, A. The manipulations of macromolecular substances during fertilization and early develop- ment of animal eggs. Amer. Zoologist 1963, 3, 109.

40. Gross, P. R., W. Spindel, and G. H. Cousineau. Decoupling of protein and RNA synthesis during deuterium parthenogenesis in sea urchin eggs. Biochem. biophys. Res. Commun. 1963, 13, 405.

41. Midgley, J. E. M. The nucleotide base composition of ribonucleic acid from several microbial species. Biochim. biophys. Acta (Amst.) 1962, 61, 513.

\section{NOTICE TO AUTHORS}

Effective January 1965, THE JOURNAL OF CLINICAL INVESTIGATION will charge $\$ 10.00$ per page for each article published, provided that the author's research funds or the institution that supported the research can bear this cost. 